\title{
Political Agreement on a Recast Asylum Reception Conditions Directive: Continuation of Tents, Containment and Discipline?
}

\section{Lieneke Slingenberg"}

In its 2020 New Pact on Migration and Asylum, the European Commission did not include a proposal for a new legal instrument on the reception conditions for asylum seekers. Instead, the Commission indicated that it supported the political agreement reached on its 2016 proposal for a recast of the Asylum Reception Conditions Directive. Even though the Commission urged the European Parliament and Council to adopt this proposal as soon as possible, this has, to date, not happened.

According to the Commission, this proposal, as amended by the political agreement reached between Parliament and Council, 'will ensure asylum seekers are received under harmonised and decent conditions throughout the EU. It will help prevent unauthorised movements within the EU by clarifying the rights and obligations of asylum seekers'. ${ }^{1}$ This chapter will examine if and how the proposal meets this purpose. After describing the background and choice of instrument in section 1, section 2 discusses the scope of the proposed recast directive, also in light of the proposed Screening Regulation. Section 3 examines the changes proposed regarding material reception conditions. As asylum seekers everywhere in Europe, from Greece to the Netherlands, are often housed in improvised premises like tents and sport halls, this section addresses, in particular, the question whether the proposal would make an end to such practises. Section 4 discusses the proposal's emphasis on restricting the freedom of movement of asylum seekers and shows how this enables the continuation of current containment policies. As regards access to the labour market, section 5 demonstrates that while the proposal ensures earlier access, it also

Associate Professor at the Amsterdam Centre for Migration and Refugee Law of the Vrije Universiteit Amsterdam. Thanks to Fadi Fahad for his editorial assistance.

1 Commission, 'New Pact on Migration and Asylum - Building on the progress made since 2016: Questions and Answers' (Press corner, 23 September 2020) $<$ https:/ec.europa.eu/commission/presscorner/detail/en/qanda_20_1723> accessed 9 November 2021. 
includes new grounds for excluding asylum seekers from employment. Section 6 examines the proposed grounds for reducing and withdrawing reception conditions and shows how the proposal both increases and limits Member States' disciplinary power in this regard. Finally, section 7 discusses the element of the proposal that most clearly ensures an increase in asylum seekers' rights: the treatment of (unaccompanied) children.

\section{Background and Choice of Instrument}

Conditions for the reception of asylum seekers have been a matter of EU law since 2003, when the first Directive on minimum standards for the reception of asylum seekers 2003/9/EC ${ }^{2}$ was adopted. As that Directive allowed Member States 'a wide margin of discretion concerning the establishment of reception conditions at national level' (see 2008 Commission proposal $^{3}$ ), a recast was adopted in 2013. In 2016, as part of the European Agenda on Migration, the European Commission published again a proposal for a recast of the Asylum Reception Conditions Directive. This was considered necessary, as the reception conditions 'continue to vary considerably between Member States both in terms of how the reception system is organised and in terms of the standards provided to applicants'. ${ }^{4}$ The proposal aims, therefore, once again to further harmonise the reception conditions in the EU. In addition, it aims to reduce incentives for secondary movements and increase applicants' self-reliance and possible integration prospects.

In 2018, the Council of the EU and the European Parliament reached provisional agreement on the proposal. However, the political representatives of the member states (in Coreper) could not agree with the compromise text and it was concluded that 'further attempts at the technical level should be made to gain further support from delegations'. ${ }^{5}$ Subsequently,

2 Council Directive 2003/9/EC of 27 January 2003 laying down minimum standards for the reception of asylum seekers [2003] OJ L031.

3 Commission, 'Proposal for a Directive of the European Parliament and of the Council laying down minimum standards for the reception of asylum seekers (Recast)' COM(2008) 815 final.

4 Commission, 'Proposal for a Directive of the European Parliament and of the Council laying down standards for the reception of applicants for international protection (Recast)' COM(2016) 465 final.

5 Council of the European Union, 'State of play and guidance for further work - Proposal for a Directive of the European Parliament and of the Council laying down 
the presidency presented some amendments to the compromise text, on the basis of which negotiations had to be reopened.

In its 2020 New Pact on Migration and Asylum, ${ }^{6}$ the European Commission indicated that it supports the political agreement reached and urged for adoption 'as soon as possible'. From the 'roadmap', it appears that this should happen in the second quarter of $2021 .^{7}$ In its 'state of play' update of September 2021, the Commission writes that it is 'mainly due to the package approach'8 that, to date, the provisional compromise reached between Parliament and Council has not been endorsed by Council and urges Parliament and Council again to ensure the quick adoption. ${ }^{9}$

Contrary to the proposals on asylum procedures ${ }^{10}$ and qualification for international protection, ${ }^{11}$ the Commission does not propose a Regulation to deal with the reception conditions of asylum seekers. According to the Commission: 'Considering the current significant differences in Member States' social and economic conditions, it is not considered feasible or desirable to fully harmonise Member States' reception conditions'. Hence, the proposal aims to further harmonise, not to fully harmonise. As the new

standards for the reception of applicants for international protection (Recast)' (2019) 5458/19.

6 Commission, 'On a New Pact on Migration and Asylum', $\operatorname{COM}(2020) 609$ final.

7 Commission, 'Annexes to the Communication from the Commission to the European Parliament, the Council and the European Economic and Social Committee and the Committee of the Regions on a New Pact on Migration and Asylum', $\operatorname{COM}(2020) 609$ final.

8 Especially Member States at the external border insist on treating all CEAS legislation as a package (Nikolaj Nielsen, 'EU 'front-line' states want clearer migration rules' (EUobserver, 26 November 2020) <https:/euobserver.com/migrati on/150196> accessed 9 November 2021.

9 Commission, Annex 1 to the Report on Migration and Asylum, 29 September 2021, $\operatorname{COM}(2021) 590$ final.

10 Commission, 'Amended proposal for a Regulation of the European Parliament and of the Council establishing a common procedure for international protection in the Union and repealing Directive 2013/32/EU' $\operatorname{COM(2020)~} 611$ final; European Commission, 'Proposal for a Regulation of the European Parliament and of the Council establishing a common procedure for international protection in the Union and repealing Directive 2013/32/EU' COM(2016) 467 final.

11 Commission, 'Proposal for a Regulation of the European Parliament and of the Council on standards for the qualification of third-country nationals or stateless persons as beneficiaries of international protection, for a uniform status for refugees or for persons eligible for subsidiary protection and for the content of the protection granted and amending Council Directive 2003/109/EC of 25 November 2003 concerning the status of third-country nationals who are longterm residents' $\operatorname{COM}(2016) 466$ final. 
instrument will still be a Directive, the provisions included in the proposal need to be implemented in national legislation after adoption.

In this chapter I will discuss the most important changes laid down in the 2016 Commission proposal and the provisional compromise text, ${ }^{12}$ published in October $2020^{13}$ and the further proposed amendments by the Council ${ }^{14}$ (referred to together as 'the proposals'), as compared to the current Asylum Reception Conditions Directive 2013/33/EU, ${ }^{15}$ against the background of relevant case law of the Court of Justice of the European Union (CJEU). I will not pay attention to the detention of asylum seekers, as this is dealt with in the chapter by Galina Cornelisse in this volume.

\section{Scope: What about the Screening Procedure?}

The provision on scope, Article 3 of Directive 2013/33/EU, has not been changed substantively by any of the proposals. However, the moment as from which Member States should provide reception conditions has been clarified in Article 16 of the proposals. This provision indicates that Member States should make material reception conditions available as from the moment applicants make their application in accordance with Article 25 of the proposed Asylum Procedure Regulation. ${ }^{16}$ This article stipulates that an application is 'made' when somebody expresses a 'wish for international protection to officials of the determining authority or other authorities referred to in Article 5(3) or (4)'. Accordingly, this would make it clear

12 Council of the European Union, 'Conditional confirmation of the final compromise text with a view to agreement - Directive 2013/33/EU of the European Parliament and of the Council of 26 June 2013 laying down standards for the reception of applicants for international protection (recast)' (2018) 10009/18 ADD 1.

13 'EU: Tracking the Pact: Secret documents on reception conditions and qualification for international protection' (Statewatch, 1 October 2020) <www.statewatch.o $\mathrm{rg} /$ news/2020/october/eu-tracking-the-pact-secret-documents-on-reception-conditi ons-and-qualification-for-international-protection> accessed 10 November 2021.

14 Council of the European Union, 'State of play and guidance for further work Proposal for a Directive of the European Parliament and of the Council laying down standards for the reception of applicants for international protection (Recast)' (2019) 5458/19.

15 Council and European Parliament Directive 2013/33/EU of 26 June 2013 laying down standards for the reception of applicants for international protection (recast) [2013] OJ L180/96.

16 Commission, 'Proposal for a Regulation of the European Parliament and of the Council establishing a common procedure for international protection in the Union and repealing Directive 2013/32/EU' COM(2016) 467 final. 
that from the moment an applicant expresses a wish to apply for international protection, (s)he falls under the scope of the Asylum Reception Conditions Directive, no formal lodging or registration is necessary. This is in conformity with the interpretation by the CJEU of the current Asylum Procedure Directive 2013/32/EU ${ }^{17}$ in the case of VL. ${ }^{18}$

In this light, it is hard to understand the Commission's remarks in the explanatory memorandum to the new Proposal for a Screening Regulation. ${ }^{19}$ The Commission states that persons who apply for international protection at the border crossing point or during the screening procedure, should be considered as applicants for international protection. However, 'the legal effects concerning the Reception Conditions Directive should apply only after the screening has ended' (italics LS), according to the Commission. This also seems to follow from Article 9(2) and (3) of the Proposal for a Screening Regulation that obliges Member States to identify special reception needs and provide adequate support. This is an obligation that already follows from the Asylum Reception Conditions Directive (see below); so, apparently, the idea is that this Directive does not yet apply. Accordingly, the different proposals (on reception conditions, asylum procedures and screening) are clearly not yet completely in line with each other. This should be clarified during the legislative procedure. In order to safeguard a dignified standard of living, which is required under the Charter (see below) and in order to ensure legal clarity and a high level of harmonisation, the Asylum Reception Conditions Directive should apply during the screening procedure.

As regards the authorities to which applicants can express their wish for international protection, the new proposals are more limited than the current provisions. The current provisions, as interpreted by the CJEU in $V L$, allow for making an application with a broad range of authorities, not limited to those that are qualified to register applications under national law. This helps, according to the CJEU, to ensure applicants effective access to the procedure. The proposed Asylum Procedure Regulation, however, limits the definition of 'making an application' to expressing a wish

17 Council and European Parliament Directive 2013/32/EU of 26 June 2013 on common procedures for granting and withdrawing international protection [2013] OJ L180/60.

18 CJEU, Ministerio Fiscal v VL, C-36/20, ECLI:EU:C:2020:495.

19 Commission, 'Proposal for a Regulation of the European Parliament and of the Council introducing a screening of third country nationals at the external borders and amending Regulations (EC) No 767/2008, (EU) 2017/2226, (EU) 2018/1240 and (EU) 2019/817' $\mathrm{COM}(2020) 612$ final. See also the chapter in this volume. 
for international protection to one of the authorities that are explicitly entrusted with registering applications under EU or national law, in line with Articles 5(3) and (4) of the proposed Regulation. For the scope of the new Asylum Reception Conditions Directive this means that applicants would no longer fall under the scope if they express their wish to an authority that is not competent to register applications.

\section{Material Reception Conditions: The End of Tents?}

While it is well known that many asylum seekers have to live in dire conditions in tent camps in Greece, also asylum seekers in Germany ${ }^{20}$ and in the Netherlands ${ }^{21}$ are currently sheltered in tents, without any privacy. 'No more Morias' is, according to the European Commission, an important aim of the new pact. ${ }^{22}$ In addition, the Commission states that the proposal for a new asylum reception conditions directive ensures decent conditions throughout Europe. Does that mean that housing asylum seekers in tents will no longer be possible under the proposals? What do the proposals stipulate as regards the quality of the conditions to be provided to asylum seekers?

\section{a) Definition of Material Reception Conditions}

Member States are required to provide asylum seekers with material reception conditions. Under the current Asylum Reception Conditions Directive 2013/33/EU, these conditions are defined as 'the reception conditions that include housing, food and clothing provided in kind, or as financial allowances or in vouchers, or a combination of the three, and a daily expenses allowance (Article $2(\mathrm{~g})$ ). The Commission proposes to add 'other

20 'Germany sees sharp rise in migrants arriving via Belarus' (Euronews, 13 October 2021) <www.euronews.com/2021/10/13/germany-sees-sharp-rise-in-migrants-arrivi ng-via-belarus $>$ accessed 9 November 2021.

21 'Almere gets tent camp to house 450 refugees as housing crisis worsens' (Dutch news, 18 October 2021) <www.dutchnews.nl/news/2021/10/almere-gets-tent-camp -to-house-450-refugees-as-housing-crisis-worsens/> accessed 9 November 2021.

22 Speech of Commissioner for Home Affairs Ylva Johansson on 17 September 2020 $<$ https://ec.europa.eu/commission/commissioners/2019-2024/johansson/announce ments/intervention-european-parliament-plenary-session-debate-need-immediate-a nd-humanitarian-eu-response_en> accessed 9 November 2021. 
essential non-food items matching the needs of the applicants in their specific reception conditions, such as sanitary items' to the definition of material reception conditions (Article 2(7)). The Compromise text limits this to 'personal hygiene products', a clear and important addition.

As regards the obligation to provide a daily expenses allowance, the Commission proposes no changes. The European Parliament agrees with this 'in order to ensure a minimum autonomy to the applicants'. The Council, however, wishes to provide Member States the possibility of providing the daily expenses allowance fully in kind or in vouchers. As a compromise, a new definition of the daily expenses allowance is included in the compromise text:

'an allowance provided to applicants periodically for them to enjoy a minimum degree of autonomy in their daily life in the form of a monetary amount, vouchers, or in kind, for example in products, or a combination of any of the three, provided that such an allowance includes a monetary amount' (Article 2(7a))

The presidency of the Council emphasized ${ }^{23}$ that this definition does not specify the starting moment for providing the monetary amount, nor the exact part that it should constitute.

The current Asylum Reception Conditions Directive contains a few additional obligations for the provision of housing in kind, for example to use premises that are specifically adapted or meant for the housing of asylum seekers; to take into consideration gender and age-specific concerns of asylum seekers when housing them; to ensure that transfers of asylum seekers to another reception facility only take place when necessary; and to ensure that reception centre personnel are adequately trained. Member States can, however, deviate from these obligations when housing capacities normally available are temporarily exhausted, provided this is duly justified and for as short as possible (paragraph 9). ${ }^{24}$ The Commission proposal does not propose significant changes to this provision. The compromise text adds two grounds for deviating from the general obligations:

23 Council of the European Union, 'Conditional confirmation of the final compromise text with a view to agreement - Reception Conditions Directive 2013/33/EU' (2018) 10009/18.

24 See on this: Lieneke Slingenberg, 'Reception Conditions Directive (recast): Relevance in Times of High Numbers of Asylum Applications' in Paul E. Minderhoud and Karin Zwaan (eds), The recast Reception Conditions Directive: Central Themes, Problem Issues, and Implementation in Selected Member States (Wolf legal publishers 2016) 9-26. 
when housing capacities normally available are temporarily unavailable due to 1) a disproportionate number of persons to be accommodated or 2) a man-made or natural disaster. This does, however, not add much, as temporary exhaustion can have many causes, which makes these two new grounds rather superfluous. The compromise adds an additional safeguard as well, by requiring Member States to include these three situations in their contingency plan (Article 28) and to inform the Commission and the European Agency for Asylum about the activation of their contingency plan.

Hence, while the inclusion of personal hygiene products is an important addition to the definition of material reception conditions, the new definition of the daily expenses allowance would provide Member States with more discretion to decide on the quality of the conditions. As regards housing, the proposals do not limit Member States' possibilities to house asylum seekers in premises that are not specifically adapted or meant for housing asylum seekers, such as tents or sport halls, but do install a control mechanism.

\section{b) The Unclear but Relevant 'Dignified Standard of Treatment'}

Member States need to ensure that material reception conditions 'provide an adequate standard of living for applicants, which guarantees their subsistence and protects their physical and mental health' (Article 16(2) of the Commission proposal). The Commission does not propose any changes as regards this standard compared to the current Directive 2013/33/EU. In three provisions, however, the Commission refers to another standard of treatment: a 'dignified standard of living'. Member States can deviate from the regular standard of treatment and merely ensure a dignified standard of living in three situations: if 1) in duly justified cases, they exceptionally set different modalities for reception conditions when an assessment of special needs is required or when housing capacities normally available are temporarily exhausted (Article 17(9));2) they are not the responsible Member State under the Dublin Regulation for the applicants concerned (Article 17a(2)); and 3) they replace, reduce or withdraw reception conditions on one of the grounds laid down in Article 19. A 'dignified standard of living' is, therefore, the absolute minimum that Member States should ensure under all circumstances, and that lies below the regular minimum level of an 'adequate standard of living' (that, on its turn, may lie below the adequate standard of treatment for nationals, see Article 16(6)). Even though the concept of a dignified standard of living is, as an absolute 
minimum standard of treatment, one of the key concepts of the Directive, this concept is not further defined. It is unclear what kind of provisions need to be available to ensure applicants a dignified standard of treatment and how this differs from the general adequate standard of treatment.

To confuse things further, the compromise text has replaced the term 'dignified standard of treatment' with 'a standard of living in accordance with Union law, including the Charter of Fundamental Rights of the European Union, and international obligations'. The general standard of treatment in the compromise text is formulated as 'an adequate standard of living for applicants, which guarantees their subsistence, protects their physical and mental health and respects their rights under the Charter of Fundamental Rights of the European Union'. As both standards of treatment refer to the Charter of Fundamental Rights, the difference between the two is even harder to understand.

In the case of Haqbin, ${ }^{25}$ the CJEU was asked to interpret the provision on reduction and withdrawal of reception conditions. The CJEU concluded, with reference to Article 1 of the Charter, that a sanction that consists in the withdrawal, even if only a temporary one, of material reception conditions relating to housing, food or clothing is irreconcilable with the requirement to ensure a dignified standard of living for the applicant.

Accordingly, the current Directive 2013/33/EU already clearly stipulates the elements of the concept of material reception conditions (housing, food, clothing) that Member States should provide and these elements are, according to the CJEU, also required to ensure a dignified standard of living. The proposals add one element (personal hygiene items), but do not provide any new and further guidance as regards the quality of these elements. In addition, the proposals explicitly allow Member States to provide these elements at a lower standard in certain enumerated circumstances. It is unclear what this lower standard entails, which leaves room for interpretation. Arguably, therefore, the proposals still leave ample room for housing applicants in tents.

25 CJEU, Haqbin v Federaal Agentschap voor de opvang van asielzoekers, C-233/18, ECLI:EU:C:2019:956. 


\section{Emphasis on Residence Restrictions: Continuation of Containment Policies}

Current policies on the reception of asylum in Europe are characterized by, and criticised for its containment of asylum seekers. ${ }^{26}$ It seems that the Commission, Council and Parliament all agree that such policies should continue, as the proposals have much more emphasis on restrictions on freedom of movement as compared to the current Asylum Reception Conditions Directive 2013/33/EU. ${ }^{27}$ This is especially the case for the compromise text, in which no less than three provisions deal with residence restrictions. Articles $6 a, 6 b$ and 7 include four different kinds of residence restrictions that increase in the degree of severity:

\begin{tabular}{|l|l|l|l|}
\hline $\begin{array}{l}\text { Arti- } \\
\text { cle }\end{array}$ & $\begin{array}{l}\text { Residence restric- } \\
\text { tion }\end{array}$ & Condition & Consequence of non-compliance \\
\hline $6 \mathrm{a}$ & $\begin{array}{l}\text { Allocate applicants to } \\
\text { specific accommoda- } \\
\text { tions }\end{array}$ & $\begin{array}{l}\text { For reasons of manage- } \\
\text { ment of their asylum } \\
\text { and reception systems }\end{array}$ & $\begin{array}{l}\text { Losing the entitlement to material re- } \\
\text { ception conditions (Article 6a(4)). }\end{array}$ \\
\hline 6b & $\begin{array}{l}\text { Allocate applicants } \\
\text { to a geographical } \\
\text { area within their ter- } \\
\text { ritory, that they can } \\
\text { only leave with per- } \\
\text { mission }\end{array}$ & $\begin{array}{l}\text { For the purpose of en- } \\
\text { suring swift, efficient } \\
\text { and effective processing } \\
\text { of applications in ac- } \\
\text { cordance with the Asy- } \\
\text { lum Procedure Regu- } \\
\text { lation, effective moni- } \\
\text { toring of applications or } \\
\text { geographic distribution } \\
\text { of applicants }\end{array}$ & $\begin{array}{l}\text { Reduction or withdrawal of the dai- } \\
\text { ly expenses allowance or reduction } \\
\text { of other material reception conditions } \\
\text { (Article 19(2)(a)). }\end{array}$ \\
\hline $7(2)$ & $\begin{array}{l}\text { Reporting obliga- } \\
\text { tions }\end{array}$ & $\begin{array}{l}\text { To ensure that the deci- } \\
\text { sions referred to in Arti- } \\
\text { cle 7(1) are respected or } \\
\text { to effectively prevent ap- } \\
\text { plicants from abscond- } \\
\text { ing }\end{array}$ & $\begin{array}{l}\text { Reduction or withdrawal of the dai- } \\
\text { ly expenses allowance or reduction } \\
\text { (Article 19(2)(a)) }\end{array}$ \\
\hline
\end{tabular}

26 See for example: René Kreichauf, 'From forced migration to forced arrival: the campization of refugee accommodation in European cities' (2018) 6 Comparative Migration Studies 7; Martina Tazzioli, 'Governing migrant mobility through mobility: Containment and dispersal at the internal frontiers of Europe' (2020) 38 Environment and Planning C: Politics and Space 3; Guiseppe Campesi, 'Between containment, confinement and dispersal: the evolution of the Italian reception system before and after the "refugee crisis" (2018) 23 Journal of Modern Italian Studies 490.

27 See also the chapter by Galina Cornelisse in this volume. 


\begin{tabular}{|l|l|l|l|}
\hline $\begin{array}{l}\text { Arti- } \\
\text { cle }\end{array}$ & $\begin{array}{l}\text { Residence restric- } \\
\text { tion }\end{array}$ & Condition & Consequence of non-compliance \\
\hline $7(1)$ & $\begin{array}{l}\text { Decide that an appli- } \\
\text { cant is only allowed } \\
\text { to reside in a specific } \\
\text { place, that they can } \\
\text { only leave with per- } \\
\text { mission }\end{array}$ & $\begin{array}{l}\text { For reasons of public or- } \\
\text { der or to effectively pre- } \\
\text { vent the applicant from } \\
\text { absconding, where there } \\
\text { is a risk of absconding }\end{array}$ & $\begin{array}{l}\text { Losing the entitlement to mate- } \\
\text { rial reception conditions (Article } \\
7(1))\end{array}$ \\
& & $\begin{array}{l}\text { Reduction or withdrawal of the } \\
\text { daily expenses allowance or re- } \\
\text { duction of other material recep- } \\
\text { tion conditions (Article 19(2)(a)) } \\
\text { Detention, provided there is still } \\
\text { a risk of absconding ((Article } 8(3) \\
\text { (c)) }\end{array}$ \\
\hline
\end{tabular}

The provisions also include different safeguards, such as in Article 6a that Member States need to ensure that applicants effectively benefit from their rights under this Directive and take into account family unit and in article $6 \mathrm{~b}$ that Member States need to ensure that the geographical area is sufficiently large, that there is access to necessary public infrastructure and that the applicants' unalienable sphere of private life is not affected. However, both these provisions also indicate that Member States are not required to adopt administrative decisions to allocate applicants and from Article 25(1) it appears that Member States do not have to enable applicants to lodge an appeal against the allocation (only against refusal of permission to leave or against the consequences for non-compliance). From the accompanying document to the compromise text it appears that allocation to a geographical area 'without any administrative or judicial decision' was of crucial importance for the Member States, on which the European Parliament had strong reservations. Article 7 has more procedural safeguards, does not allow Member States to act without any administrative decision and does provide for judicial protection.

As all three provisions have 'may clauses', ${ }^{28}$ use general and broad conditions, and two of them allow Member States to act without an administrative decision, this is a clear example of an issue on which Member States still have a lot of discretion. This is further strengthened by the proposed definition of absconding. This is an important concept, as it is not only used as a new ground for restricting applicants' freedom of movement (Article 7) but also as a new ground of detention (Article 8) and for reduction and withdrawal of material reception conditions (Article 19). Until now, EU law does not contain a definition of this concept,

28 The Commission proposed to lay down in Article 7 that Member States 'shall' where necessary decide on the residence of applicants in a specific place, but this is not formulated as an obligation anymore in the compromise text. 
even though it is already a relevant concept in for example the Dublin III Regulation (EU) No 604/2013..$^{29}$ The Commission proposes to define absconding as 'the action by which an applicant, in order to avoid asylum procedures, either leaves the territory where he or she is obliged to be present $(\ldots)$ or does not remain available to the competent authorities or to the court or tribunal' (Article 2(10)). This definition includes the intention to avoid asylum procedures in the concept of absconding. In the compromise text, this definition has been changed and simply refers to the 'action by which an applicant does not remain available to the competent administrative or judicial authorities' (Article 2(11)). Leaving the territory of the Member State without authorisation is mentioned as an example of absconding, but only if this is for reasons which are not beyond the applicant's control. The compromise text does no longer refer to any intention behind or purpose for not remaining available. From accompanying documents to the compromise text, ${ }^{30}$ it appears that the definition of absconding is almost entirely based on the Council position, as this was one of the provisions of 'crucial importance to the Member States'. Deleting a reference to the intention is, therefore, intentional. Even though the ordinary meaning of the term 'absconding' implies 'the intent of the person concerned to escape from someone or to evade something', according to the CJEU in the case of Jawo, ${ }^{31}$ this will not be part of the EU definition if the compromise text on this is adopted. Probably this is due to the fact that the authorities will likely encounter considerable difficulties in providing proof of the intentions of persons concerned, as also noted by the CJEU in the case of Jawo.

Accordingly, even though the current containment policies are heavily criticised, the proposals do not severely limit the possibilities of Member States to implement such a policy. On the contrary, the proposals' emphasis on residence restrictions could encourage Member States to use them, albeit with some limitations stemming from additional safeguards included in the proposals.

29 Council and European Parliament Regulation (EU) No 604/2013 of 26 June 2013 establishing the criteria and mechanisms for determining the Member State responsible for examining an application for international protection lodged in one of the Member States by a third-country national or a stateless person [2013] OJ L180/31.

30 Council of the European Union, 'Conditional confirmation of the final compromise text with a view to agreement - Reception Conditions Directive 2013/33/EU' (2018) 10009/18.

31 CJEU, Jawo v Bundesrepublik Deutschland, C-163/17, ECLI:EU:C:2019:218. 


\section{Labour Market: Earlier Access but More Exclusions}

Next to harmonisation, one of the main aims of the recast of the Directive is to increase applicants' self-reliance and possible integration prospects. In line with this, the Commission proposes to oblige Member State to provide applicants with access to the labour market six months after the lodging of the application, instead of the current nine months. The compromise text stipulates that the deadline of six months starts after the registration of the application (for which, contrary to the formal lodging of an application, strict deadlines are laid down in the proposal for an Asylum Procedures Regulation). Both proposals do not change that access to the labour market only needs to be provided if no decision on the application for international protection has been taken by the competent authorities within these six months. Accordingly, if the authorities decide to reject the application for international protection within six months (which is the normal time limit for deciding on an asylum application under the proposed Asylum Procedure Regulation), applicants can still be denied access to employment during the entire asylum procedure, including the appeal phase. Also the possibility to give priority to nationals, Union citizens or lawfully staying TCN's when filling a specific vacancy stays intact.

In addition, the proposals introduce two new exclusions from the labour market. First of all, Member States are not allowed to grant access to the labour market to applicants whose application is examined in an accelerated asylum procedure, in accordance with Article 40(1)(a)-(f) of the proposed Asylum Procedure Regulation. The compromise text adds that if access is already granted, it will be withdrawn. This includes applicants who have withheld relevant facts, are from a safe country of origin or are found to have made an application merely to delay or frustrate a return decision. Since the proposals use the term 'shall', Member States have no discretion to grant them the possibility to work.

Secondly, the proposals lay down that applicants who are subject to a Dublin transfer decision should be excluded from access to the labour market (Article 17a of the Proposals). The Court of Justice has recently ruled that under the current Directive 2013/33/EU applicants as regards to whom a transfer decision has been taken cannot be excluded from the labour market ${ }^{32}$. Interestingly, the Court of Justice did not only base its

32 CJEU, KS and Others $v$ The International Protection Appeals Tribunal Ireland and Others, C-322/19 and C-385/19, ECLI:EU:C:2021:11. 
judgment on the text of the Directive but also on the requirement to ensure a dignified standard of living and on the Directive's objective to 'promote the self-sufficiency of applicants'. The reasoning adopted by the Court would, therefore, still be relevant if the new Proposals are adopted. In this light, the lawfulness of these exclusions from the labour market would be questionable.

The proposals further lay down that applicants should receive equal treatment with nationals as regards terms of employment, freedom of association and affiliation, education and vocational training, branches of social security, recognition of diplomas and access to appropriate schemes for the assessment, validation and recognition of applicants' prior learning outcomes and experience. This kind of equal treatment also helps, according to the Commission, to avoid distortions in the labour market. Even though equal treatment on these issues will be the main rule, the proposals allow Member States to restrict this in different ways, for example by excluding grants and loans related to education and vocational training or social security benefits which are not dependent on periods of employment or contribution. On these issues, Member States, therefore, retain some discretion.

\section{Reduction and Withdrawal: Disciplining Asylum Seekers}

Since the first Directive on reception conditions (2003/9/EC) Member States have been allowed to reduce or withdraw reception conditions on a limitative number of grounds, for example if an applicant does not comply with certain obligations, has lodged a subsequent application or has abandoned the place of residence. In this way, the threat of poorer living conditions or homelessness can be used to influence asylum seekers' behaviour. By adding two new grounds for withdrawing or reducing reception conditions, the proposals increase this kind of disciplinary power. At the same time, the proposals also limit this power, be reducing the grounds for withdrawal of all reception benefits and by more often requiring a strong justification.

Just as in the 2008 proposal $^{33}$ for a recast of this first Directive, the Commission proposes in its 2016 proposal to delete the possibility to entirely

33 Commission, 'Proposal for a Directive of the European Parliament and of the Council laying down minimum standards for the reception of asylum seekers (Recast)' $\operatorname{COM}(2008) 815$ final. 
withdraw all reception conditions on one of these grounds. Instead, the Commission proposes to allow Member States to reduce or withdraw the daily expenses allowance or to replace financial benefits with benefits in kind. The accompanying document to the compromise text shows that, again, the Member States are not willing to give up their possibility to entirely withdraw all reception conditions. Yet, they are willing to limit this to the situation that an applicant 'has seriously or repeatedly breached the rules of the accommodation centre or has behaved in a violent or threatening manner in the accommodation centre'. Based on the case of Haqbin, however, this possibility might no longer be lawful, as the CJEU has ruled that a withdrawal of material reception conditions on the basis of violent behaviour is not in conformity with Member States' obligation to ensure a dignified standard of living and with the proportionality principle. ${ }^{34}$

A new ground for withdrawing material reception conditions is laid down in Article 17a of the proposals. Just like access to employment (see section 5 above), Member States should end the provision of material reception conditions when another Member State is responsible for dealing with the application on the basis of the Dublin Regulation. ${ }^{35}$ Contrary to the grounds for reducing and withdrawing laid down in Article 19 of the proposals, this provision does not use a 'may' clause, which means that Member States do not have any discretion in this regard. In addition, the safeguards laid down in the provision on withdrawal and reducing conditions (e.g. as regards proportionality, justification, objectivity, all addressed in a decision) do not apply. The compromise text holds that the transfer decision shall state that the relevant reception conditions have been withdrawn, unless a separate decision is issued. Apparently, a separate decision is not necessary for withdrawing the reception conditions based on a transfer decision. However, one important safeguard is included in Article 17a: Member States are still required to ensure the absolute minimum standard of living (see section 3 above) after the withdrawal of the regular reception conditions, which should include, as the case of Haqbin suggests, at least some kind of housing, food and clothing.

34 CJEU, Haqbin v Federaal Agentschap voor de opvang van asielzoekers, C-233/18, ECLI:EU:C:2019:956.

35 The Commission proposed to also allow Member States to reduce reception conditions if an asylum seeker has been sent back after having absconded to another Member State (Article 19(2)(h) Commission proposal), but this ground is not included in the compromise text. 
In addition to withdrawing material reception conditions in case of violent behaviour or after a transfer decision, the compromise text proposes to allow Member States to reduce or withdraw the daily expenses allowance or, if this is duly justified and proportionate, reduce other material reception conditions on one of the enumerated grounds. As compared to the current Asylum Reception Conditions Directive 2013/33/EU, this means that the justification requirement now also applies to decisions to reduce (and not withdraw) material reception conditions (other than the daily expenses allowance). However, contrary to the Commission proposal, the possibility to reduce material reception conditions stays intact. I believe the Commission's proposal to only allow Member State to reduce the daily expenses allowance or to replace financial benefits with benefits in kind provides clearer rules. It is hard to imagine how reduced benefits in kind are different from a situation in which those benefits are withdrawn, but a dignified standard of living is still ensured, as required under the proposals.

The proposals contain one new ground for reduction/replacement of reception conditions: material reception conditions can be reduced/replaced and the daily expenses allowance can be withdrawn if applicants fail to participate in mandatory integration measures. The compromise text adds an exception for circumstances outside the applicant's control. Even though both proposals introduce a shorter time limit for accessing the labour market as a means to increase integration prospects for applicants, both proposals apparently also see integration as a duty for refugees that can be enforced by withholding benefits.

\section{Better Protection of (Unaccompanied) Children}

While the foregoing sections discussed proposals that would provide some increase in rights and protection for asylum seekers, but would also preserve significant discretion for Member States to continue current policies of containment and 'campization' and included new grounds to exclude asylum seekers from rights, the proposals as regards children give a less mixed picture, as they clearly increase children's rights. Children profit from the more clearly formulated general obligation to identify special needs; their representation is better safeguarded; and they profit from earlier access to the mainstream education system. 


\section{a) Concept of Vulnerability Deleted}

Both the old (2003/9/EC) and the current Asylum Reception Conditions Directive (2013/33/EU) refer to the concept of vulnerability and stipulate that Member States should take into account the specific situation of vulnerable persons (Articles 17 and 21 respectively). Whereas Directive 2003/9/EC limited this obligation to persons found to have special needs, Directive 2013/33/EU lays down the opposite and holds that only vulnerable persons may be considered to have special needs. Both directives also include a list of examples of vulnerable groups. In its 2016 proposal the Commission deletes all references to vulnerability and specifies that Member States need to take into account the specific situation of applicants with special reception needs. The Commission also proposes to delete the list of examples of vulnerable groups, but the compromise text includes and extends this list of examples of persons who are 'more likely to have special reception needs'. This might blur the obligation a bit again, as the possible special needs of all applicants need to be assessed. In addition, the proposals further clarify the assessment procedure for identifying special needs, by including specific obligations for the personnel of the competent authorities and, in the compromise text, a deadline for completing the assessment.

\section{b) Representatives for Unaccompanied Minors}

The proposals lay down a time limit for Member States to designate a guardian/representative for an unaccompanied minor. The Commission proposes to oblige Member States to assign a guardian for unaccompanied minors within five working days of the making of an application. The compromise text sticks to the current formulation of a 'representative' instead of a guardian and extends the time limit for designating one to 15 , and exceptionally 25 , working days (both at the wish of the Council). However, this proposal obliges Member States to designate a person who is suitable to provisionally assist the minor until a representative has been designated. Both proposals further clarify Member States' obligations by including a definition of guardian/representative and by stipulating that a guardian/representative is not put in charge of a disproportionate number of unaccompanied minors. In the compromise text this is even set on a maximum of 30 (exceptionally 50). This maximum number was included at the wish of the European Parliament. 


\section{c) Access to Education}

The Commission did not propose any changes to the provision on schooling and education for minors. Under the current Directive 2013/33/EU, Member States need to grant minors access to the education system under similar conditions as their own nationals, but are allowed to provide this education on accommodation centres and to postpone access for three months from the date the asylum application is lodged (Article 14). The compromise text increases children's rights significantly in this regard, as it proposes to stipulate that access to education should be granted in the mainstream education system and can only be postponed for a maximum of two months. Only by way of a temporary measure, for a maximum of one month, are Member states allowed to provide education outside the mainstream system. The accompanying document to the compromise text suggests that these safeguards are included because they were of fundamental importance to the European Parliament.

\section{Conclusions}

If the current compromise text on a recast for the Asylum Reception Conditions Directive will be adopted, as urged by the Commission in the New Pact on Migration and Asylum, many current practises and policies can be continued. As this chapter shows, this is true for housing asylum seekers in improvised premises such as tents or sport halls, subjecting asylum seekers to geographical restrictions and reporting duties, coercing asylum seekers to comply with obligations in the asylum procedure by threatening to reduce or withhold basic provisions and excluding asylum seekers from access to the labour market during the entire asylum procedure. In addition, new possibilities for restrictive treatment are proposed, such as withdrawing reception conditions if another Member State is responsible, coercing asylum seekers to participate in integration activities and allocating applicants to a geographical area, that they can only leave with permission, without any administrative or judicial decision.

Even though the proposals do not put an end to these practises and policies, they do propose more and better safeguards against deprivation, for example by requiring Member States to inform the Commission if they rely on exceptional housing arrangements and by requiring Member States to ensure a minimum standard of treatment in all circumstances. In addition, the proposals include a few new rights for applicants, for example to be provided with personal hygiene products, to equal treatment as 
nationals as regards some working conditions and social security benefits, and (for minors) to timely access to the mainstream education system.

The proposals are not completely in line with recent CJEU case law, that is adopted after the compromise text was drafted. This is not necessarily a problem. The legislator is, of course, free to change the legislation. If the judgments are based on the wording of the current provisions (e.g. the V.L. case on the scope of the Directive or the Jawo case on the definition of absconding), these judgments will no longer be relevant if the proposals are adopted. But where the proposals refer to human dignity and/or the EU Charter on Fundamental Rights and the CJEU (partly) based its interpretation on those rights and concepts as well (such as in the Haqbin case on temporary withdrawing reception conditions and the K.S. and others case on access to employment), this becomes more problematic. As regards the exclusions from employment and from all material reception conditions, the lawfulness of the proposals is questionable. The concept of a 'dignified standard of living', and the differences with the general standard of living for applicants (if any), need, therefore, to be further clarified in the final negotiations. 
